Jurnal Mahasiswa Ilmu Komputer (JMIK)

Vol. 01, No. 01, Maret 2021

\title{
PERANCANGAN APLIKASI PENGOLAHAN DATA MUTASI OBAT PADA PKD PUSKESMAS RAMAN UTARA LAMPUNG TIMUR
}

\author{
Septi Elia Rahmawati ${ }^{(1)}$ Sudarmaji ${ }^{(2)}$ \\ Jurusan Ilmu Komputer, Fakultas Ilmu Komputer,Universitas Muhammadiyah Metro \\ Jl.Gatot Subroto No.100 Yosodadi Kota Metro, Telpon :(0725)42445-Fax(0725)42454 \\ E-mail: Majidarma5022@gmail.com
}

\begin{abstract}
ABSTRAK
Tugas akhir ini merupakan hasil dari penelitian berupa analisis dan observasi yang sedang berjalan dan dilakukan pada Puskesmas Raman Utara Lampung Timur khususnya pada pengelolahan mutasi obat. Kondisi saat ini, manajemen pengelolahan mutasi obat pada puskesmas raman utara masih menggunakan lembaran kertas HVS dalam mencatat obat keluar, menggunakan excel dalam pencatatan obat masuk maupun pelaporan data mutasi obat, dalam kasus tersebut terjadinnya kehilangan catatan, kesalahan pengetikan nama ataupun dalam perhitungan obat itu sendiri. Pencarian data obat masih dilakukan secara manual yaitu dengan mencari dokumen secara satu persatu. Hal tersebut menumbulkan masalah lainnya seperti pembuatan laporan data mutasi obat yang sering terhambat. Pengelolahan data obat merupakan suatu hal yang sangat penting dilakukan guna keperluan pengelolahan manajemen yang baik pada suatu instansi kesehatan, dan pada penelitian ini menghasilkan database mutasi yaitu tabel data obat masuk dan data obat keluar. Entity relationship diagram (ERD) dan relasi tabel. Tampilan input data obat masuk maupun input data obat keluar, serta tampilan laporan obat masuk, obat keluar, dan mutasi obat keseluruhan ataupun pertanggalnya. Dengan adanya rancangan aplikasi pengelolahan data mutasi obat pada PKD Puskesmas Raman Utara diharapkan dapat mengurangi terjadinya kesalahan pencatatan data, dapat memperudah dan mempercepat dalam proses pembuatan laporan mutasi obat PKD Puskesmas Raman Utara Lampung Timur.
\end{abstract}

Kata Kunci: Aplikasi Pengolahan Data Mutasi Obat Puskesmas Raman Utara, Mutasi Obat Puskesmas Raman Utara, java netbeans IDE 802, iReport.

\section{PENDAHULUAN}

Pengelolahan manajemen yang baik dalam lingkup kerja merupakan suatu hal yang sangat diharuskan dalam suatu instansi atau perusahaan. Hal ini terlihat dari hasil proses kinerja setiap pegawai. Ketepatan waktu dalam pengelolahan suatu data menjadi tolak ukur pengelolahan manajemen yang baik. Penyediaan teknologi dan informasi yang memumpuni sangat berpengaruh dalam pengelolahan tersebut. Pengolahan yang didukung dengan kemajuan teknologi akan mempermudah dalam pengelolahan manajemen pada setiap instansi atau perusahaan yang sedang berjalan, seperti 
Vol. 01, No. 01, Maret 2021

membantu dalam proses mendapatkan informasi secara cepat, tepat dan akurat. Berbagai macam proses yang dilakukan secara manual dapat ditata kembali scara terperinci untuk mendapatkan data yang lebih akurat, sebagaimana pengelolahan data mutasi obat pada instansi kesehatan. Manajemen mutasi obat memiliki peran penting dalam sistem kesehatan nasional. Obat berperan untuk mendukung pelayanan kesehatan di semua tingkat pelayanan kesehatan. Pentingnya pengelolaan mutasi diprediksi akan meningkat, khususnya di era Jaminan Kesehatan Nasional (JKN). Manajemen mutasi obat yang baik akan memberikan kemudahan untuk mengelola data pengadaan, penyimpanan, dan distribusi dalam rangka untuk memenuhi permintaan pasien yang semakin lama semakin meningkat. Puskesmas merupakan salah satu lembaga kesehatan yang memilki sistem yang komplit dalam pengolahan datanya, yang mengharuskan semua data terolah dengan baik, tersimpan dengan rapi dan mudah ditelusuri dari tempat penyimpanan apabila diperlukan. Pusat Kesehatan Masyarakat (Puskesmas) adalah Fasilitas Kesehatan Tingkat Pertama (FKTP) yang bertanggung jawab atas kesehatan masyarakat pada bagian wilayah kecamatan. Dalam peraturan Menteri
Kesehatan Nomor 75 tahun 2014 tentang

Pusat Kesehatan Masyarakat menyatakan bahwa Puskesmas berfungsi menyelenggarakan Upaya Kesehatan Masyarakat (UKM) dan Upaya Kesehatan Perorangan (UKP) tingkat pertama. Berdasarkan Keterangan para tokoh, Puskesmas Raman Utara dibangun pada tahun 1958 oleh jawatan trasmigrasi, dengan menggunakan dana swadaya masyarakat, yang diberi nama balai pengobatan. Seiring dengan perkembangan penduduk dan kemajuan zaman, maka pada tahun 1970-an status balai pengobatan berubah menjadi Puskesmas Raman Utara. Pusksmas Raman Utara merupakan pusat kesehatan masyarakat yang beralokasi di Jalan Merdeka No. 4 Kota Raman, Kecamatan Raman Utara, Kabupaten Lampung Timur dengan luas wilayah $4051 \mathrm{~km}^{2}$. Letak geografis Puskesmas Raman Utara adalah sebelah timur berbatasan dengan wilayah kerja Pusat Kesehatan Masyarakat Kecamatan Purbolinggo, sebelah selatan wilayah kerja Pusat Kesehatan Masyarakat kecamatan Sukaraja Nuban, sebelah utara wilayah kerja Pusat Kesehatan Masyarakat Rejo Katon, dan sebelah barat wilayah kerja Pusat Kesehatan Masyarakat Rejo Katon. Wilayah kerja Puskesmas Raman Utara terdiri dari desa Kota Raman, desa Raman 
Aji, desa Rukti Sediyo, desa Raman Endra, desa Ratna Daya dan desa Rejo Binangun yang berada di wilayah Kecamatan Raman Utara. Kepala Unit Pelaksana Teknis Dinas (KUPTD) Puskesmas Raman Utara bernama Munjiyah, S.ST. Jumlah karyawan Puskesmas Raman Utara pada saat ini adalah 40 orang, terdiri dari 30 Pegawai Negri Sipil (PNS) dan 10 Tenaga Kerja Suka Rela (TKS).

Dalam pembuatan judul tugas akhir penulis juga mempertimbangkan yang telah di cantumkan ke dalam ayat suci Al-quran surah asy-syuara ayat 78-82 yang berbunyi:

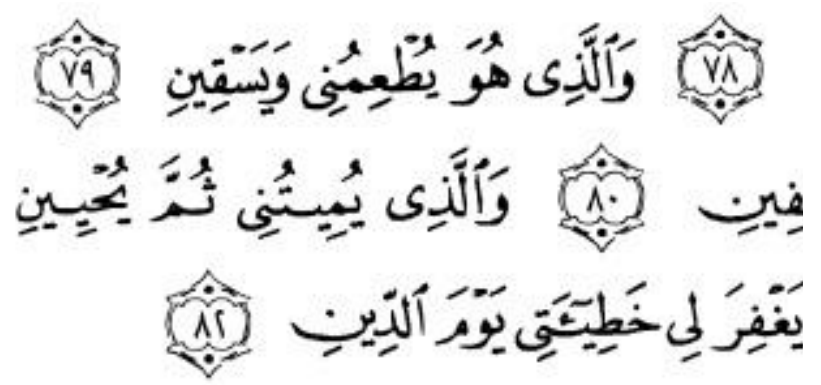

"yaitu Tuhan yang telah menciptakan aku, maka dialah yang menunjuki aku, dan Tuhanku, yang dia memberi makan dan minum kepadaku, dan apabila aku sakit, dialah yang menyembuhkan aku, dan yang akan mematikan aku, kemudian akan menghidupkan aku (kembali), dan yang amat kuinginkan akan mengampuni kesalahanku pada hari kiamat." (Asy-syuara ayat 78-82).
Kondisi saat ini dalam proses pengelolahan mutasi obat pada PKD (Pusat Kesehatan Dasar) Puskesmas Raman Utara masih dilakukan secara manual, yaitu resep obat yang diberikan kepada pihak apoteker bagian pelayanan farmasi dikumpulkan untuk kemudian didata kembali ke dalam lembaran kertas HVS yang telah di print out berisikan tabel data obat keluar. Pengumpulan data yang dilakukan secara manual mengakibatkan hilangnya beberapa data resep obat. Dalam proses pencarian data obat, hilangnya data resep obatpun sangat berpengaruh terhadap manajemen kineja selanjutnya yaitu data obat yang hilang harus bisa ditemukan kembali dengan cara menghitung stok obat secara satu persatu menggunakan kalkulator. Selama akhir bulan data mutasi obat dikumpulkan menjadi satu dan kemudian diketik ke dalam Excel untuk dicetak dan dilaporkan kepada pihak dinas terkait. Pada proses penginputan data obat, terjadinya duplikasi dan kesalahan dalam pengetikan data obat sangatlah memungkinkan, dalam proses pengerjaanya membutuhkan waktu yang cukup lama karena penamaan obat yang harus benarbenar sesuai. Jika dalam proses sebelumnya pendataan mutasi obat tejadi kesalahan maka pelaporan jumlah data stok obat masuk dengan jumlah data stok obat keluar 
dikhawatirkan tidak sama, dan selama jumlah stok obat keluar dan stok obat masuk tidak sama maka data obat akan dicari dan dihitung kembali secara satu-persatu dan pada akhirnya pembuatan laporan data mutasi obat setiap bulan tidak sesuai dengan tanggal yang telah ditetapkan. Berdasarkan permasalahan yang ditemui pada lokasi penelitian sesuai dengan uraian diatas, maka penulis mengajukan judul tugas akhir dengan judul "PERANCANGAN APLIKASI PENGOLAHAN DATA MUTASI OBAT PADA PKD (PUSAT KESEHATAN DASAR) PUSKESMAS RAMAN UTARA LAMPUNG TIMUR”.

\section{KAJIAN PUSTAKA DAN LANDASAN TEORI}

\subsection{Definisi Perancangan}

Dalam proses pembuatan aplikasi yang akan digunakan pada suatu instansi/perusahaan, hendaknya terlebih dahulu membuat suatu racangan dari sistem yang akan dibuat. Rancangan dari suatu sistem haruslah dibuat dengan tujuan guna memberi gambaran umun dari sistem yang akan berjalan nantinya kepada setiap penguna. Berikut ini terdapat pula beberapa teori mengenai pengertian perancangan dari para ahli. Perancangan menurut Rizky yang dikutip Saputra, dkk (2014:129). Perancangan adalah sebuah proses untuk mendefinisikan suatu yang dikerjakan denga menggunkan tehnik yang bervariasi serta didalam melibatkan deskripsi mengenai arsitektur serta detail komponen dan juga keterbatasan yang akan dialami dalam proses pengerjaannya. Perancangan menurut
Prahasta yang dikutip Saputra, dkk (2014:129),

perancangan merupakan suatu proses pengunaan berbagai prinsip dan teknik untuk tujuan-tujuan pendefenisian suatu perangkat, proses, atau sistem hingga ketingkat detail tertentu yang memungkinkan realisasi (implementasi) bentuk fisiknya (termasuk aplikasi perangkat lunak).

Bedasarkan dua definisi perancangan diatas, penulis menarik kesimpulan bahwa perancangan merupakan suatu pola yang dibuat untuk mengatasi masalah yang sedang dihadapi guna memenuhi kebutuhan dari pengguana seperti perencanaan dan pembuatan sketsa suatu sistem.

\subsection{Definisi Aplikasi}

Aplikasi berasal dari kata aplication yang artinya penerapan, lamaran, penggunaan. Secara istilah aplikasi adalah program siap pakai yang dibuat untuk melaksanakan suatu fungsi bagi pengguna atau aplikasi yang lain dan dapat digunakan oleh sasaran yang dituju.

Menurut Budiharto (2013:5), "Aplications merupakan program yang dapat berjalan tersendiri (stand alone computer), dari mulai program yang simpel sampai dengan program yang besar dan rumit". Menurut Jogiyanto yang dikutip Riswaya (2014:62), "penggunaan dalam suatu komputer, instruksi (instruction) atau pernyataan (statement) yang disusun sedemikian rupa sehingga komputer dapat memproses input menjadi output". Berdasarkan dua definisi aplikasi diatas, maka penulis menarik kesimpulan bahwa aplikasi merupakan penerapan suatu program untuk melaksanakan suatu tugas sehingga komputer dapat meproses input menjadi output.

\subsection{Definisi Data}

Data merupakan suatu bahan yang kemudian akan dikelola berupa bahan atau fakta yang 
berhubungan dengan kenyataan yang kemudian dipergunakan untuk mendapatkan suatu informasi. Berikut ini merupakan pengertian data menurut para ahli. Menurut Sutanta yang dikutip Astuti (2011:35), "Data dapat disfinisikan sebagai bahan keteragan tentang kejadian-kejadian nyata atau faktafakta yang dirumuskan dalam kelompk tertentu yang tidak acak yang menunjukan jumlah, tindakan atau hal". Menurut Laudon dan Laudon yang dikutip Kadir (2009:3), "Fakta-fakta mentah yang mewakili kejadian-kejadian yang berlangsung dalam organisasi atau lingkungan fisik sebelum ditata dan diatur kedalam bentuk yang dapat dipahami dan digunakan orang".

Menurut Kadir (2003:3), "Deskripsi tentang benda, kejadian, aktifitas dan transaksi yang tidak mempunyai makna atau tidak berpengaruh secara langsung kepada pemakai". Dari pengertian tersebut, maka dapat disimpulkan bahwa data merupakan catatan dari suatu obyek nyata tentang benda, kejadian, aktivitas dan transaksi yang belum ditata dan diatur.

\subsection{Definisi Pengolahan Data}

Pengolahan data merupakan suatu bentuk dari proses untuk menghasilkan suatu informasi. Berikut ini adalah pengertian pengolahan data menurut para ahli.

Menurut Jogianto yang dikutip oleh Arman (2013:165)

Pengolahan (processing) adalah proses data yang diolah melalui suatu model menjadi informasi, penerima kemudian menerima informasi tersebut, membuat suatu keputusan dan melakukan tindakan, yang berarti menghasilkan suatu tindakan yang lain yang akan membuat sejumlah data kembali. Menurut Ladjamudin (2013:9), "Pengolahan data adalah masa atau waktu yang digunakan untuk mendeskripsikan perubahan bentuk data menjadi formasi yang memiliki kegunaan".
Dari pengertian tersebut, maka dapat disimpulkan bahwa pengolahan data merupakan proses untuk mendeskripsikan bentuk data input menjadi informasi yang berguna (Output).

\subsection{Definisi Mutasi}

Menurut Kamus Besar Bahasa Indonesia, mutasi dalam administrasi dan kepegawaian adalah pemindahan pegawai dari satu jabatan ke jabatan lain; mutasi dalam istilah biologi yaitu perubahan yang terjadi mendadak dalam kromosom; kedokteran dan fisikologi perubahan dalam bentuk, kualitas atau sifat lain. Dalam mutasi pengertian mutasi obat, penulis menyimpulkan bahwa mutasi obat adalah suatu bentuk pemindahan obat-obatan, atau proses transaksi keluar masuknya obat.

\subsection{Definisi Obat}

Obat merupakan komponen penting dalam pelayanan kesehatan. Pengelolaan obat yang efisien diharapkan dapat memberikan dampak positif bagi rumah sakit dan pasien secara medik. Hal ini dikarenakan obat merupakan komponen yang sangat strategis dalam pelayanan pasien. Berikut ini merupakan pengertian obat menurut para ahli. Pengertian Obat menurut Hanik (2014:25),

Obat adalah bahan atau panduan yang dimaksudkan untuk mendapatkan diagnose, mencegah, menghilangkan, menyembuhkan gejala penyakit, kelainan badaniah atau rohaniah pada manusia atau hewan untuk memperelok bahan atau bagian tubuh manusia.

\subsection{Definisi Farmasi}

Farmasi (bahasa Inggris: pharmacy, bahasa Yunani: pharmacon, yang berarti obat) merupakan salah satu bidang profesional kesehatan yang merupakan kombinasi dari ilmu kesehatan dan ilmu kimia, yang mempunyai tanggung jawab memastikan 
efektivitas dan keamanan penggunaan obat. Pelayanan kefarmasian adalah bentuk pelayanan dan tangggung jawab langsung profesi apoteker dalam pekerjaan kefarmasian untuk meningkatkan kualitas hidup pasien (Menkes RI, 2004). Pelayanan kefarmasian merupakan proses kolaboratif yang bertujuan untuk mengidentifikasi, mencegah, dan menyelesaikan masalah obat dan masalah yang berhubungan dengan kesehatan. Pelayanan farmasi merupakan salah satu kegiatan di rumah sakit yang menunjang pelayanan kesehatan yang bermutu. Hal tersebut diperjelas dalam Keputusan Menteri Kesehatan Nomor 288/Menkes/SK/III/2002 tentang Standar Pelayanan Rumah Sakit, yang menyebutkan bahwa pelayanan farmasi rumah sakit adalah bagian yang tidak terpisahkan dari sistem pelayanan kesehatan rumah sakit yang berorientasi kepada pelayanan pasien, penyediaan obat yang bermutu, termasuk pelayanan farmasi klinik, yang terjangkau bagi semua lapisan masyarakat.

\subsection{Bahasa Pemrograman}

Bahasa Pemrograman (programming language) adalah sebuah instruksi standar untuk memerintah komputer agar menjalankan fungsi tertentu. Bahasa pemrograman ini merupakan suatu himpunan dari aturan sintaks dan semantik yang dipakai untuk mendefinisikan program komputer. Java Menurut Budiharto (2013:1), "Java adala sebuah bahasa pemrograman dan platform yang handal untuk mengembankan aplikasi interprise". Dalam Tugas Akhir yang penulis lakukan penulis menggunakan platform bahasa Java Standar Edition (Java SE). Menurut Budiharto (2013:2), "Mendefinisikan segala sesuatu dari bahasa pemrgraman java tungkat tinggi yang digunakan untuk aplikasi jaringan komputer, akses keamanan, database, grapical user interface (GUI), dan menguraikan (parsing)".

\subsection{Tipe Data dan Fungsi}

Java mempunyai 8 macam tipe data yang sederhana dan referensi/komposit. Tipe sederhana meliputi byte, short, int, long, char, float, double dan boolean yang terbagi menjadi 3 tipe. Sedangkan tipe data referensi meliputi class, array dan interface. Tipe data sederhana

Integer (Bilangan Bulat)

Tipe data yang masuk menjadi bagian ini adalah byte, short, int dan long. Semua tipe data ini bersifat Signed, yaitu bisa mempresentasikan nilai positif dan negatif. Tidak seperti tipe data lainnya, Java tidak mendukung tipe data unsigned yang hanya bisa mempresentasikan nilai postif.

Byte

Type byte umumnya digunakan pada saat kita bekerja dengan sebuah data stream dari suatu file maupun jaringan, yaitu untuk kepeluan proses membaca/menulis. Selain itu, tipe ini juga digunakan saat bekerja dengan data biner yang tidak kompatibel dengan tipe-tipe lain yang didefiniskan di dalam Java.

Short

Pada umumnya diaplikasikan pada komputer-komputer 16-bit, yang saat ini semakin jarang keberadaanya.

Int

Tipe ini merupakan tipe yang paling banyak dipakai dalam merepresentasikan angka dalam Java, dikarenakan dianggap paling efisien dibandingkan dengan tipetipe integer lainnya. Tipe Int banyak digunakan untuk indeks dalam struktur pengulangan maupun dalam konstruksi sebuah array. Selain itu, secara teori setiap ekspresi yang melibatkan tipe integer byte, short, int, long) semuanya 
akan dipromosikan ke int terlebih dahulu sebelum dilakukan proses perhitungan.

\section{Long}

Tipe ini digunakan untuk kasus-kasus tertentu yang nilainya berada di luar rentang tipe int, karena tipe ini punya range paling tinggi dibanding Integer lainnya. Dengan kata lain, tipe long terpaksa digunakan jika data memiliki range diluar range int.

\section{Floating Point (Bilangan Pecahan)}

Tipe floating-point digunakan untuk merepresentasikan nilai-nilai yang mengandung pecahan atau angka decimal di belakang koma, seperti 3.1416,5.25, dan sebagainya. Bilangan semacam ini disebut sebagai bilangan riil. Dalam Java tipe ini dibedakan menjadi dua jenis, yaitu float, dan double.

\section{Float}

Tipe ini digunakan untuk menandakan nilainilai yang mengandung presisi atau ketelitan tunggal (single-precision) yang menggunakan ruang penyimpanan 32-bit. Presisi tunggal biasanya lebih cepat untuk prosesor-proesor tertentu dan memakan ruang penyimpanan setengah kali lebih sedikit dibandingkan presisi ganda (double precision). Permasalahan yang timbul dari pemakaian tipe float untuk nilai-nilai yang terlalu kecil atau justru terlalu besar, karena nilai yang dihasilkan akan menjadi tidak akurat.

\section{Double}

Tipe ini mengandung tingkat ketelitian ganda atau presisi ganda (double precision) dan enggunakan ruang penyimpanan 64-bit untuk menyimpan nilai. Tipe double tentu lebih cepat untuk melakukan perhitunganperhitungan matematis daripad tipe float. Untuk perhitungan yang bersifat bilangan riil dan menghasilkan hasil yang lebih akurat, maka lebih baik menggunakan tipe double.

\section{Char}

Tipe data char merupakan tipe untuk menyatakan sebuah karakter. Javamenggunakan karakter Unicode untuk merepresentasikan semua karakter yang ada. Unicode ialah sekumpulan karakter yang terdapat pada semua bahasa, seperti bahasa Latin, Arab, Yunani dan lain-lainnya. Karena bahasa Java dirancang untuk dapat diterapkan di berbagai macam platform, maka Java menggunakan karakter Unicode yang membutuhkan ukuran 16-bit. Untuk karakter-karakter yang tidak dapat diketikkan secara langsung melalui keyboard, java menyediakan beberapa escape sequence pasangan karakter yang dianggap sebagai karakter tunggal. Escape sequence tidak dianggap sebagai String, melainkan tetap sebagai tipe karakter khusus.

\section{Boolean}

Tipe boolean adalah tipe data yang digunakan untuk menampung nilai logika, yaitu nilai yang hanya memiliki dua buah kemungkinan (benar atau salah). Tipe ini ditandai dengan kata kunci boolean. Dalam bahasa Java, nilai benar dipresentasikan dengan kata kunci true dan nilai salah dengan kata kunci false.

Netbeans IDE 8.0.2

Netbeans IDE 8.0.2

Menurut Wahana (2015:20), "Netbeans adalah sebuah aplikasi IDE yang digunakan oleh developer software komputer unuk menulis, meng-compile, mencari kesalahan, untuk menyebarkan program".

Swing Controls

Berikut terdapat kegunaan dari setiap tools Komponen Swing Controls dapat dilihat pada tabel 2.1.Tabel 2.2 Daftar Tools 
Vol. 01, No. 01, Maret 2021

Komponen Palette Swing Controls pada Netbeans IDE 8.0.2

(Sumber: Hudaya 2015:11)

\begin{tabular}{|c|c|c|}
\hline No. & Tools & Fungsi \\
\hline 1. & Label & $\begin{array}{l}\text { Untuk memberikan keterangan } \\
\text { tambahan atau indentitas pada tombol } \\
\text { atau perintah lainnya. }\end{array}$ \\
\hline 2. & Toggle Button & $\begin{array}{l}\text { Button yang selalu berada dalam salah } \\
\text { satu dari dua kondisi. Setiap klik pada } \\
\text { button akan merubah dari kondisi satu } \\
\text { ke kondisi lainnya. }\end{array}$ \\
\hline 3. & Radio Button & $\begin{array}{l}\text { Untuk meminta user agar memilih } \\
\text { satu dari lebih dua pilihan, contoh } \\
\text { penggunaannya adalah ketika kita } \\
\text { mengisi data diri untuk pilihan jenis } \\
\text { kelamin. }\end{array}$ \\
\hline 4. & Combo box & $\begin{array}{l}\text { Berfungsi untuk menyisipkan } \\
\text { beberapa pilihan / perintah, sehingga } \\
\text { dengan Combo Box ini lebih } \\
\text { menghemat tempat, karena dalam } \\
\text { Combo Box ini terdiri dari beberapa } \\
\text { pilihan. }\end{array}$ \\
\hline 5. & Text Field & $\begin{array}{l}\text { Untuk membuat kolom agar kelak } \\
\text { bisa diisi perintah-perintah teks atau } \\
\text { angka oleh user, semisal pada } \\
\text { pembuatan aplikasi kalkulator "text } \\
\text { field" berfungsi menampilkan hasil } \\
\text { dari hitungan kalkulator tersebut. }\end{array}$ \\
\hline No. & Tools & Fungsi \\
\hline 6. & Scroll Bar & $\begin{array}{l}\text { Untuk menggeser jendela (windows) } \\
\text { secara vertikal. }\end{array}$ \\
\hline 7. & Progress & $\begin{array}{l}\text { Digunakan untuk menampilkan status } \\
\text { proses. }\end{array}$ \\
\hline 8. & Password Field & $\begin{array}{l}\text { Tempat untuk mengisikan password } \\
\text { yang kita miliki. }\end{array}$ \\
\hline 9. & Separator & $\begin{array}{l}\text { Berfungsi sebagai "sekat" atau } \\
\text { pemisah antar garis yang ada pada } \\
\text { aplikasi atau software yang nantinya } \\
\text { akan dibuat. }\end{array}$ \\
\hline 10. & Editor Pane & $\begin{array}{l}\text { Sebuah panel yang digunakan untuk } \\
\text { mengedit tulisan. }\end{array}$ \\
\hline 11. & Tabel & $\begin{array}{l}\text { Menampilkan atau menyisipkan tabel } \\
\text { pada aplikasi yang nantinya akan kita } \\
\text { buat. }\end{array}$ \\
\hline
\end{tabular}

\begin{tabular}{|c|c|c|}
\hline 12. & Button & $\begin{array}{l}\text { Kontrol yang tampil pada layar } \\
\text { dengan bentuk tertentu yang mirip } \\
\text { dengan tombol persegi panjang } \\
\text { dengan tulisan di tengahnya. }\end{array}$ \\
\hline 13. & Check Box & $\begin{array}{l}\text { Memilih lebih dai satu pilihan, dengan } \\
\text { menyimpan data dan akan } \\
\text { menampilkannya ketika di klik. }\end{array}$ \\
\hline No. & Tools & Fungsi \\
\hline 14. & Button Group & $\begin{array}{l}\text { Untuk menggabungkan seluruh button } \\
\text { supaya menjadi satu kesatuan fungsi. }\end{array}$ \\
\hline 15. & List & Untuk menampilkan beberapa item. \\
\hline 16. & Text area & $\begin{array}{l}\text { Tempat mengetikkan tulisan yang } \\
\text { berada dalam kotak yang mempunyai } \\
\text { fungsi scroll. }\end{array}$ \\
\hline 17. & Slider & $\begin{array}{l}\text { Berfungsi sebagai visualisasi proses } \\
\text { perjalanan dari sebuah musik atau } \\
\text { video. }\end{array}$ \\
\hline 18. & Spinner & $\begin{array}{l}\text { Berisi angka yang diletakkan secara } \\
\text { ringkas atau berupa daftar, ketika kita } \\
\text { membutuhkan angka lebih kecil, kita } \\
\text { tinggal klik tanda panah sampai } \\
\text { muncul angka yang kita inginkan, } \\
\text { atau sebaliknya misalkan kita butuh } \\
\text { angka lebih besar klik tanda panah } \\
\text { sampai muncul angka yang kita } \\
\text { inginkan. }\end{array}$ \\
\hline 19. & Text pane & $\begin{array}{l}\text { Menampilkan teks dan membolehkan } \\
\text { user untuk mengeditnya. }\end{array}$ \\
\hline 20. & Tree & $\begin{array}{l}\text { Menampilkan data dalam bentuk } \\
\text { hirarkis. }\end{array}$ \\
\hline
\end{tabular}

\section{METODE}

Metodelogi adalah sekumpulan peraturan, kegiatan, prosedur, pekerjaan yang digunakan oleh pelaku suatu disiplin ilmu guna mencapai suatu tujuan. Dalam memperoleh data dari instansi tempat penelitian guna menyusun tugas akhir, penulis menggunakan metode-metode yaitu sebagai berikut:

\section{Studi Lapangan}

Studi lapangan adalah pengumpulan data yang secara langsung mempelajari yang 
Jurnal Mahasiswa IImu Komputer (JMIK)

Vol. 01, No. 01, Maret 2021

berkaitan dengan masalah yang sedang dihadapi. Adapun studi lapangan yang penulis lakukan adalah dengan teknik :

$\sqrt{ }$ Pengamatan (Observation)

Dengan cara melakukan penelitian pengamatan langsung terhadap kegiatan yang dikerjakan pada Puskesmas Raman Utara Lampung Timur. Penulis dapat mengetahui secara langsung alur sistem pekerjaan yang berjalan pada saat ini. (Terlampir foto-foto penelitian).

\section{$\checkmark$ Wawancara(Interview)}

Yaitu penulis melakukan kegiatan wawancara/tanya jawab secara langsung sambil bertatap muka dengan "Bapak Ida Bagus Santikayana" sebagai Kepala Tata Usaha Puskesmas Raman Utara serta bidan terkait "Ibu Yunita Kristiani” sebagai apoteker Puskesmas Raman Utara. (Terlampir tabel wawacara peneitian).

\section{$\sqrt{ }$ Dokumentasi (Documetation)}

Dokumentasi yaitu penelitian yang dilakukan penulis dengan cara mengumpulkan data/dokumen yang dibutuhkan pada Puskesmas Raman Utara lampung Timur. Adapun data/dokumen penelitian yang didapatkan penulis dari tempat penelitian yaitu: dokumen data mutasi obat PKD (Pusat Kesehatan Dasar) Puskesmas Raman Utara, Kartu pesediaan barang . (Terlampir data/dokumen penelitian).

\section{Studi Pustaka}

Studi pustaka yang penulis lakukan untuk menambah beberapa hal yang tidak penulis dapatkan dalam studi lapangan seperti mempelajari literatur maupun artikel yang berkaitan dengan perancangan aplikasi, database serta unsur-unsur lain sehingga dapat memperlancar pelaksanaan penulisan masalah yang dihadapi.

\section{PEMBAHASAN}

\section{A. Hasil Penelitian}

Hasil penelitian yang penulis lakukan pada Puskesmas Raman Utara Lampung Timur adalah penulis memperoleh data dan informasi mengenai kegiatan instansi pelaksanaan pengendalian mutasi obat pada bagian farmasi dan mengetahui masalah manajemen pengelolahan kegiatan pelaksanaan seperti pencarian data obat, dan penyimpanan data obat yang terdapat pada PKD (Pusat Kesehatan Dasar) Puskesmas Raman Utara Lampung Timur.

\section{B. Rancangan Aplikasi}

Dalam perancangan suatu program, diperlukan bebebrapa tahapan yang harus dilalui penulis untuk menentukan arah dari program yang akan dirancang. Seperti yang 
dilakuakan penulis untuk membuat aplikasi yang penulis ajukan. Dimulai dari pengumpulan data, analiasa sistem, menentukan dan membuat alur sistem, membuat relasi tabel, membuat database, merancang tampilan program, sampai pada hasil pembuatan program (output) berdasarkan analisa yang diperoleh yaitu pengolahan data mutasi obat pada PKD (Pusat Kesehatan Dasar) Puskesmas Raman Utara Lampung Timur.

\section{Tujuan Rancangan Sistem}

Tujuan dari perancangan sistem tersebut adalah guna menganalisis perancangan aplikasi pengolahan data mutasi obat pada PKD (Pusat Kesehatan Dasar) Puskesmas Raman Utara Lampung Timur. Perancangan ini diusulkan sebagai bahan masukan yang dapat dipertimbangkan untuk mempermudah dan meningkatkan efektifitas kerja, khususnya untuk pengolahan data mutasi obat dalam pencarian data maupun pembuatan laporan pada PKD (Pusat Kesehatan Dasar) Puskesmas Raman Utara Lampung Timur.

\section{Gambaran Umum Sistem yang}

\section{Diusulkan}

Sistem informasi yang diusulkan memiliki beberapa keunggulan dari sistem yang sedang berjalan. Sistem ini mudah digunakan, mempermudah dan mempercepat proses penyimpanan dan pencarian data transaksi pada PKD (Pusat Kesehatan Dasar) Puskesmas Raman Utara Lampung Timur.

\section{Rancangan Prosedur yang Diusulkan}

Pada tahapan rancangan prosedur ini bertujuan untuk menghasilkan rancangan aplikasi pengolahan data mutasi obat pada PKD (Pusat Kesehatan Dasar) Puskesmas Raman Utara Lampung Timur yang berbasis komputer dan telah menggunakan database. Adapun rancangan proses ini mencangkup aliran sistem informasi, diagram konteks, data flow diagram yang dapat menjelaskan aliran data yang diproses hingga menghasilkan informasi yang diinginkan.

\section{Kebutuhan Sumber Daya}

Berdasarkan kebutuhan dari aplikasi yang diajukan penulis, kapasitas yang diperlukan daam suatu komputer sebagai berikut.

\section{Perangkat Keras (Hardware)}

Kebutuhan hardware minimal yang dibutuhkan untuk menggunakan apikasi yang penulis usulkan adalah sebagai berikut.

a. CPU dengan Processor intel Core i3

b. Memory (RAM) $2 G B$

c. Hardisk $350 \mathrm{~GB}$

d. Keyboard

e. Monitor

f. Mouse 


\section{g. Printer}

\section{Perangkat Lunak (Software)}

Pada rancangan yang diusulkan, penulis menggunakan beberapa software pendukung dalam pengolahan data mutasi obat pada PKD (Pusat Kesehatan Dasar) Puskesmas Raman Utara. Adapun software pendukung tersebut.
a. Sistem Oprasi Microsoft Windows 7
b. Java Netbean 8.0.2
c. Хатрp
d. Browser (google chrome)
e. $M y S q l$
f. iReport

\section{Perangkat Pikir (Brainware)}

Untuk melakasanakan apliaksi yang sudah dirancang dalam mengelolah aplikasi yang penulis usulkan pengolahan tersebut dibutuhkan 1 orang oprator Komputerr/IT, dan peugas karyawan yang bewenang dalam bagian farmasi (sebagai admin) untuk menginpu-kan data obat masuk ataupun data obat keluar pada PKD (Pusat Kesehatan Dasar) Puaskesmas Raman Utara.

\section{Rancangan Sistem Informasi yang Diusulkan}

Alir sistem yang diusulkan tidak merubah tujuan ataupun fungsi dari sistem yang sedang berjalan. Beberapa perubahan di dalam proses mutasi obat pada PKD (Pusat Kesehatan Dasar) Puskesmas Raman Utara dilakukan untuk membuat sistem yang lebih baik. Berikut adalah aliran informasi yang diusulkan: Dimulai dari data obat yang diterima dari dinas atau belanja obat terkait di-input-kan ke data obat masuk kedalam database sebagai data obat masuk. Setelah itu pada proses keluaran obat, pasien yang telah ditangani dokter dan telah membawa resep dari dokter yang kemudian diberikan ke petugas bagian farmasi. Setelah petugas yang berjaga menerima resep, petugas farmasi akan menginputkan data obat yang harus diterima pasien. Dari inputan obat pasien yang diterima, maka stok pada obat akan otomatis mengurang. Data stok obat masuk yang telah diinputkan akan bisa dicetak laporannya begitupun data stok obat keluar. Data obat yang dicetak kemudian bisa untuk dilaporkan ke pihak dinas terkait guna pelaporan mutasi obat. namun sebelum laporan tersebut dikirimkan kepada pihak dinas, maka laporan darta ersebut terlebih dahulu ditandatangani oleh penanggung jawab bagian farmasi dan KUPTD (Kepla Unit Pelayanan Teknis Dinas) Puskesmas Raman Utara Lampung Timur.

\section{Rancangan Diagram Conteks}

Diagram konteks ini merupakan sebuah proses yang berada di level pusat. Diagam 
konteks pada gambar 4.1 menggambarkan tentang prosedur program dari pengolahan data mutasi obat yaitu data stok obat masuk dan data stok obat keluar pada PKD (Pusat Kesehatan Dasar) Puskesmas Raman Utara Lampung Timur.

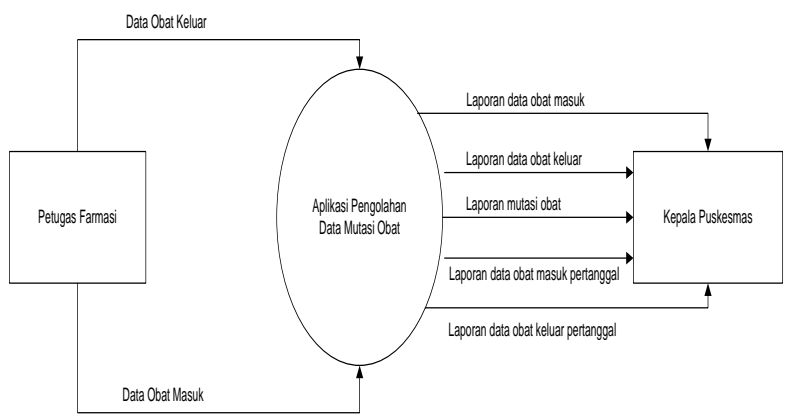

\section{Gambar 4.1 Diagram Konteks yang}

\section{Diusulkan}

\section{Rancangan Data Flow Diagram (DFD)}

Rancangna data flow diagram membantu untuk meahami sistem secara lgika, terstruktur dan jelas. Rancangan data flow diagram dibawah ini merupakan tehnik untuk menggambarkan prosesproses yang terjadi dalam suatu sistem dan merupakan gambaran rincian dari diagram konteks.

\section{a. Data Flow Diagram Level 1}

Gambar 4.2 menggambarkan tentang prosedur program dari pengolahan pemasukkan data stok obat hingga pengolahan data pengeluaran stok obat atau bisa disebut data mutasi obat pada PKD (Pusat Kesehatan Dasar) Puskesmas Raman Utara Lampung Timur.

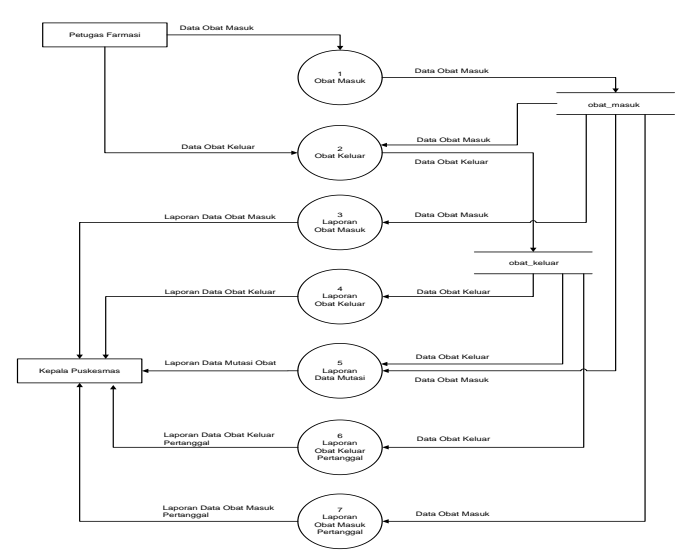

\section{Gambar 4.2 Data Flow Diagram}

(DFD) Level 1 yang Diusulkan

\section{Rancangan Bagan Alir Dokumen}

Rancangan bagian alir dokumen menggambarkan arus data dan dokumen yang melalui berbagai proses terkomputerisasi. Bagan alir dokumen obat masuk yang diusulkan pada PKD (Pusat Kesehatan Dasar) Puskesmas Raman Utara Lampung Timur dapat dilihat pada gambar 4.3 
Jurnal Mahasiswa IImu Komputer (JMIK)

Vol. 01, No. 01, Maret 2021

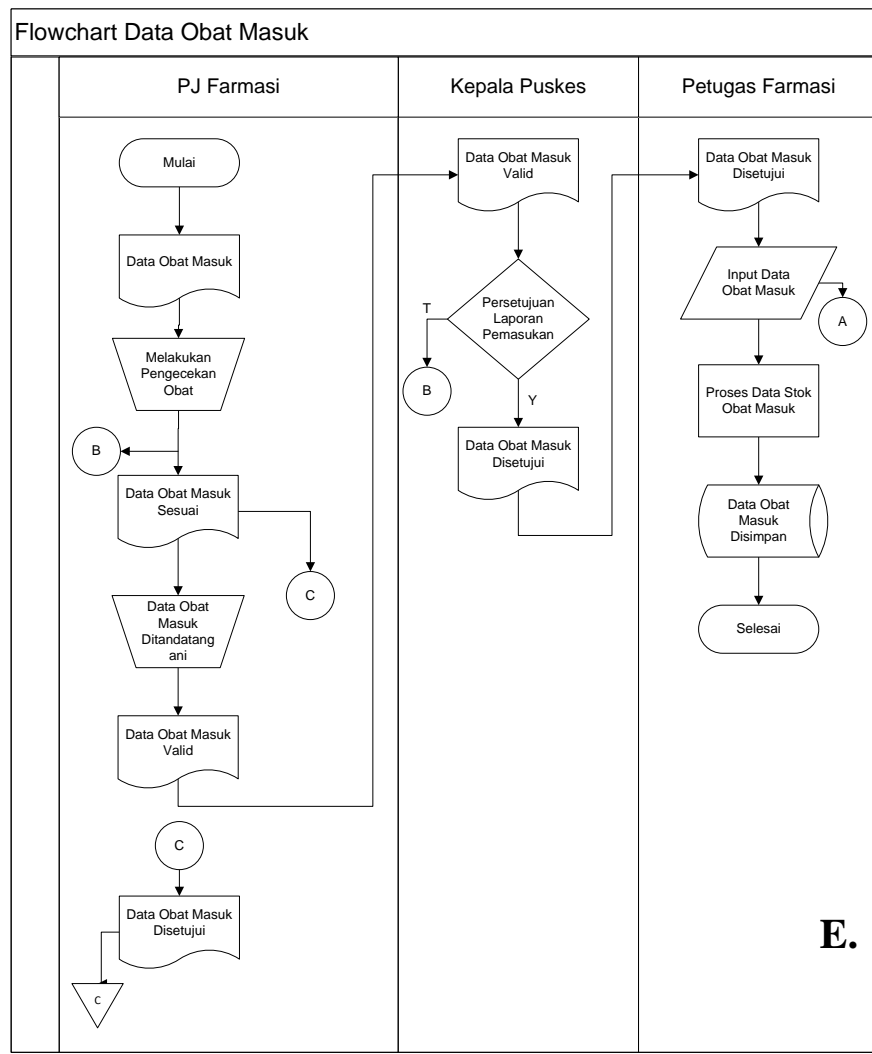

Flowchart Data Obat Keluar

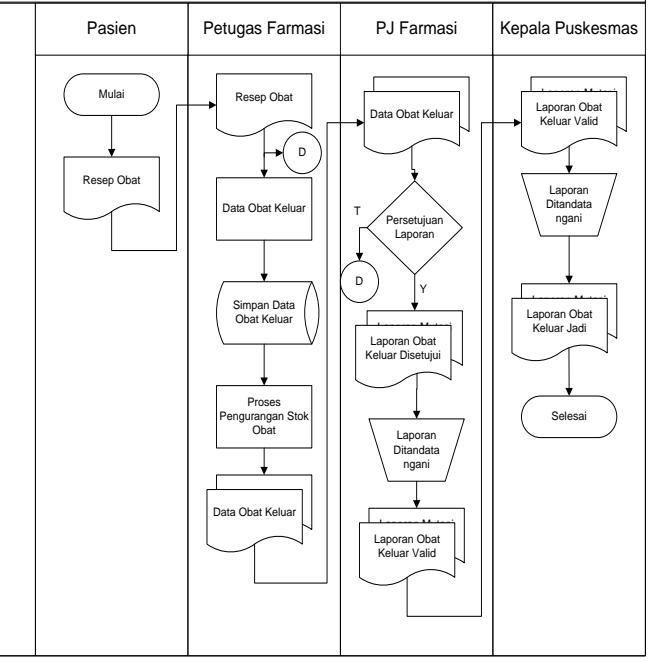

Gambar 4.4 Bagan Alir Dokumen

Obat Keluar yang Diusulkan

E. Rancangan Basis Data

\section{Tabel Data Admin}

Tabel data admin difungsikan sebagai

Gambar 4.3 Bagan Alir Dokumen

\section{Obat Masuk yang Diusulkan}

Bagan alir dokumen obat masuk yang diusulkan pada PKD (Pusat Kesehatan

Dasar) Puskesmas Raman Utara Lampung Timur dapat dilihat pada gambar 4.4 tempat penyipanan data-data petugas yang diberikan tanggung jawab sebagai administrator pada PKD (Pusat Kesehatan Dasar) Puskesmas Raman Utara Lampung Timur bagian farmasi yang berupa username dan password login guna meminimalisir dampak penyalah gunaan data obat kepada petugas lainnya. Berikut adalah struktur tabel admin.

Nama tabel : admin

Primary key $:-$

Jumlah field $: 2$

Keterangan : admin terdiri dari struktural 
farmasi dan

operator

komputer/IT.

Berisikan

nama dari

penguna

program

(admin) dan

password dari

admin tersebut.

Tabel 4.1 Tabel Data Admin yang

Diusulkan

\begin{tabular}{|l|l|c|c|l|}
\hline No & $\begin{array}{l}\text { Name } \\
\text { (File } \\
\text { Field) }\end{array}$ & Type & Length & keterangan \\
\hline 1. & $\begin{array}{l}\text { id_admin } \\
(*)\end{array}$ & int & 11 & No. Urut \\
\hline 2. & username & Varchar & 30 & $\begin{array}{l}\text { Nama } \\
\text { pengguna }\end{array}$ \\
\hline 3. & password & Varchar & 120 & Kunci sandi \\
\hline
\end{tabular}

\section{Tabel Data Obat Masuk}

Tabel data obat masuk difungsikan sebagai tempat penyipanan data-data obat yang telah diinputkan masuk seagai data stok obat pada PKD (Pusat Kesehatan Dasar) Puskesmas Raman Utara Lampung Timur. Berikut adalah struktur tabel obat masuk.

Nama tabel

: obat_masuk

Primary key

: kd_obat

Jumlah field
Keterangan

: data obat

masuk

didapatkan dari

dinas dan data

dari belanja

obat

menggunakan

dana dari JKN.

Berisikan

tentang data

obat

\section{Tabel 4.2 Tabel Data Obat Masuk}

yang

\section{Diusulkan}

\begin{tabular}{|l|l|c|c|l|}
\hline $\begin{array}{l}\mathbf{N} \\
\mathbf{o}\end{array}$ & $\begin{array}{l}\text { Name (File } \\
\text { Field) }\end{array}$ & Type & $\begin{array}{c}\text { Lengt } \\
\mathbf{h}\end{array}$ & $\begin{array}{c}\text { Keterang } \\
\text { an }\end{array}$ \\
\hline 1. & kd_obat(*) & Integer & 30 & No. obat \\
\hline 2. & nama_obat & $\begin{array}{r}\text { Varch } \\
\text { ar }\end{array}$ & 120 & $\begin{array}{l}\text { Nama } \\
\text { Obat }\end{array}$ \\
\hline 3. & kemasan & $\begin{array}{c}\text { Varch } \\
\text { ar }\end{array}$ & 30 & Kemasan \\
\hline 4. & harga_satuan & Integer & 30 & $\begin{array}{l}\text { Harga } \\
\text { satuan } \\
\text { obat }\end{array}$ \\
\hline 5. & stok_awalbulan & Integer & 30 & $\begin{array}{l}\text { Stok awal } \\
\text { obat }\end{array}$ \\
\hline 6. & $\begin{array}{l}\text { tanggal_penerima } \\
\text { an }\end{array}$ & Date & - & $\begin{array}{l}\text { Tanggal } \\
\text { terima }\end{array}$ \\
\hline 7. & asal_obat & Varch & 30 & Asal obat \\
\hline 8. & total_harga & Integer & 30 & $\begin{array}{l}\text { Total } \\
\text { harga obat }\end{array}$ \\
\hline
\end{tabular}

Keterangan Field:

a. Kd_obat adalah bentuk penomeran untuk menginput obat. Bersifat Auto Increment. 
b. Harga_satuan adalah berisi harga dari setiap satu buah obat.

c. Stok_awalbulan adalah berisistok atau jumlah obat masuk yang akan diimputkan.

d. Total_harga adalah berisi total harga keseluruhan obat, yaitu stok awal bulan * harga satuan.

\section{Tabel Data Obat Keluar dan Mutasi}

Tabel data obat keluar dan mutasi difungsikan sebagai tempat penyipanan data-data obat yang telah diinputkan masuk seagai data obat keluar sekaigus mutasi obat pada PKD (Pusat Kesehatan Dasar) Puskesmas Raman Utara Lampung Timur. Berikut adalah struktur tabel obat keluar.

$\begin{array}{ll}\text { Nama tabel } & \text { :obat_keluar } \\ \text { Primary key } & : \text { kd_keluar } \\ \text { Jumlah field } & : 10 \\ \text { Keterangan } & : \text { data obat } \\ & \text { keluar } \\ & \text { didapatkan dari } \\ & \text { data yang } \\ & \text { diinputkan } \\ & \text { setiap obat } \\ & \text { keluar. }\end{array}$

Tabel 4.3 Tabel Data Obat Keluar

dan Mutasi yang

Diusulkan

\begin{tabular}{|c|c|c|c|c|}
\hline $\begin{array}{l}\mathbf{N} \\
\mathbf{0}\end{array}$ & $\begin{array}{c}\text { Name (File } \\
\text { Field) }\end{array}$ & Type & $\begin{array}{c}\text { Lengt } \\
\text { h }\end{array}$ & $\begin{array}{c}\text { keteranga } \\
\text { n }\end{array}$ \\
\hline 1. & kd_keluar $(*)$ & Integer & 11 & $\begin{array}{l}\text { No obat } \\
\text { keluar }\end{array}$ \\
\hline 2. & kd_obat $(* *)$ & Integer & 11 & No. Obat \\
\hline 3. & tanggal & Date & - & $\begin{array}{l}\text { Tanggal } \\
\text { keluar }\end{array}$ \\
\hline 4. & nama_pasien & $\begin{array}{c}\text { Varcha } \\
\text { r }\end{array}$ & 120 & $\begin{array}{l}\text { Nama } \\
\text { pasien }\end{array}$ \\
\hline 5. & umur & Integer & 11 & $\begin{array}{l}\text { Umur } \\
\text { pasien }\end{array}$ \\
\hline 6. & jumlah_obat & Integer & 11 & $\begin{array}{l}\text { Jumlah } \\
\text { obat keluar }\end{array}$ \\
\hline 7. & antibiotik & $\begin{array}{c}\text { Varcha } \\
\text { r }\end{array}$ & 11 & $\begin{array}{l}\text { Penguanan } \\
\text { antibiotik }\end{array}$ \\
\hline 8. & nama_obat & $\begin{array}{c}\text { Varcha } \\
\text { r }\end{array}$ & 120 & Nama obat \\
\hline 9. & dosis & $\begin{array}{c}\text { Varcha } \\
\text { r }\end{array}$ & 11 & $\begin{array}{l}\text { Dosis } \\
\text { pemakaian }\end{array}$ \\
\hline $\begin{array}{l}10 \\
.\end{array}$ & $\begin{array}{l}\text { lama_pemakaia } \\
\mathrm{n}\end{array}$ & $\begin{array}{c}\text { Varcha } \\
\text { r }\end{array}$ & 30 & $\begin{array}{l}\text { Lama } \\
\text { penggunaa } \\
\text { n }\end{array}$ \\
\hline 11 & $\begin{array}{l}\text { sesuai_pedoma } \\
\mathrm{n}\end{array}$ & $\begin{array}{c}\text { Varcha } \\
\text { r }\end{array}$ & 11 & $\begin{array}{l}\text { Kesesuaian } \\
\text { pedoman }\end{array}$ \\
\hline 12 & stok_awal & Integer & 30 & $\begin{array}{l}\text { Stok awal } \\
\text { obat }\end{array}$ \\
\hline 13 & stok_akhir & Integer & 11 & $\begin{array}{l}\text { Stok akhir } \\
\text { obat }\end{array}$ \\
\hline
\end{tabular}

Keterangan Field:

a. Kd_keluar adalah bentuk penomeran untuk menginput obat keluar. Bersifat Auto Increment.

b. Kd_obat adalah bentuk nomer obat yang difungsikan untuk merelasi tabel obat masuk

c. Jumlah_obat adalah inputan jumlah obat yang akan keluar. 
d. Stok_akhir adalah berisistok atau jumlah obat yang telah dikurangkan, yaitu stok akhir jumlah obat

\section{Entity Releationship Diagram (ERD)}

$$
\text { Relasi tabel menunjukkan }
$$
hubungan antar tabel dalam sebuah database program. Relasi bisa ditunjukkan melalui sebuah diagram yakni Entity Relationship Diagram (ERD). Berikut gambar 4.5 rancanga relasi database db_mutasiobat.

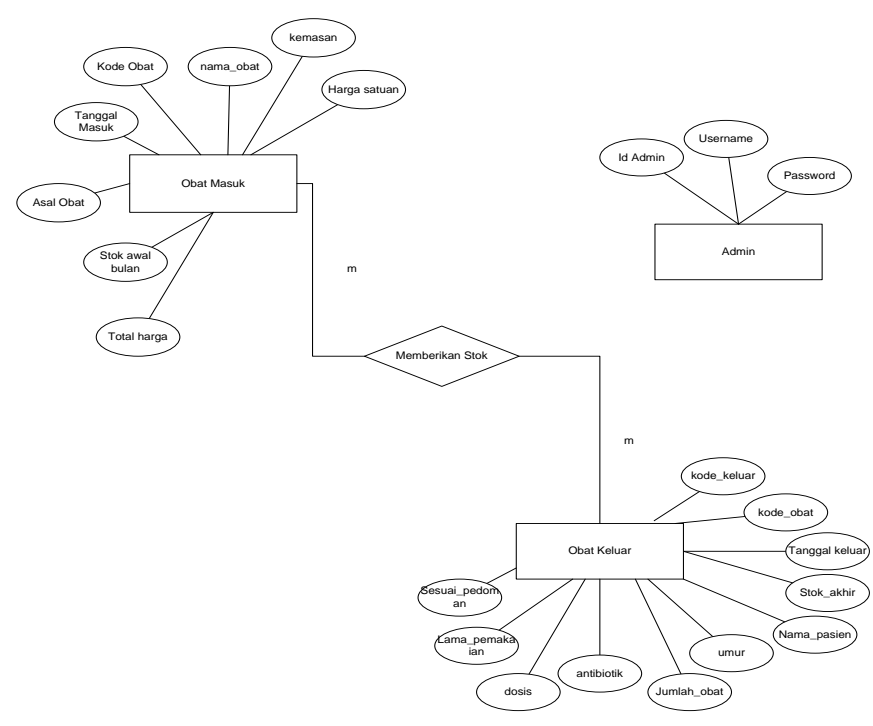

Gambar 4.5 Entity Releationship Diagram (ERD) yang Diusulkan

\section{Relasi Tabel}

Adapun rancangan database secara keseluruhan berserta relasinnya yang diusulkan seperti pada gambar 4.6 dibawah ini.

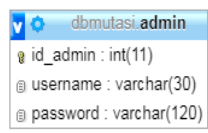

\begin{tabular}{|c|c|}
\hline & vo dbmutasi obat_keluar \\
\hline O dbmutasi obat_masuk & okd_keluar: int(11) \\
\hline ied_obat: int(30) & a kd_obat: int(11) \\
\hline (1) nama_obat: $\operatorname{varchar}(120)$ & I tanggal : date \\
\hline (1) kemasan : varchar(30) & (1) nama_pasien : varchar(120) \\
\hline \# hargasatuan : int(30) & \# umur: int(11) \\
\hline \# stok_awal : int(30) & \# jumlah_obat: int(11) \\
\hline I t tanggal : date & 目 antibiotik: varchar(11) \\
\hline \# total_harga : int( $(30)$ & (1) nama_obat: $\operatorname{varchar}(120)$ \\
\hline (1) asal_obat: $\operatorname{varchar}(30)$ & (1) dosis : $\operatorname{varchar(11)}$ \\
\hline & (1) lama_pemakaian : varchar(30) \\
\hline & (1) sesuai_pedoman : varchar(11) \\
\hline & \# stok_awal : int (30) \\
\hline & \# stok_akhir: int(11) \\
\hline
\end{tabular}

\section{Gambar 4.6 Relasi Tabel yang Diusulkan}

F. Rancangan Antar Muka Sistem

\section{Rancangn Form Login}

Tampilan login berfungsi sebagai tempat untuk masuk akses utama pada program dengan cara memasukkan Userame dan Password. Gambar 4.7 merupakan rancangan form ogin yang penulis usulkan.

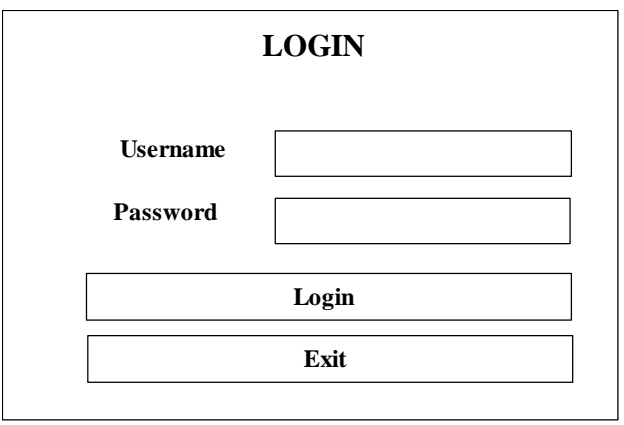

\section{Gambar 4.7 Form Login yang}

\section{Diusulkan}

\section{Rancangan Form Menu Utama}

Form menu utama adalah form yang berisi daftar menu form yang ada di dalam program. Rancangan form menu utama dapat dilihat pada gambar 4.8. 


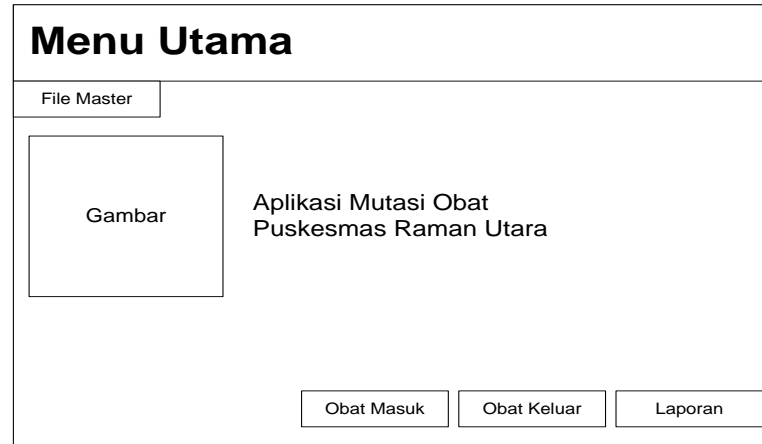

Gambar 4.8 Form Menu Utama yang
- 4 Rancangan Form Data Obat Keluar

Form data obat keluar berfungsi untuk menginputkan data keluar obat yang dimana data obat akan diinputkan setiap terdapat keluaran obat pada PKD (Pusat Kesehatan Dasar) Puskesmas Raman Utara. Seperti pada gambar 4.10 yang diusulkan.

\section{Diusulkan}

\section{Rancangan Form Data Obat Masuk}

Form data obat masuk berfungsi untuk menginputkan data masuk obat yang dimana data obat didapat dari belanja obat JKN dan dinas pada PKD (Pusat Kesehatan Dasar) Puskesmas Raman Utara. Seperti pada gambar 4.9 yang diusulkan.

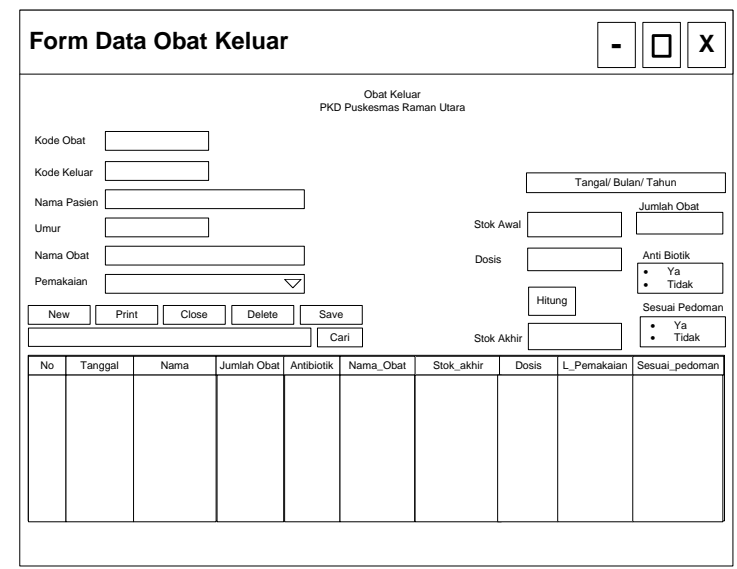

Gambar 4.10 Form Obat Keluar yang

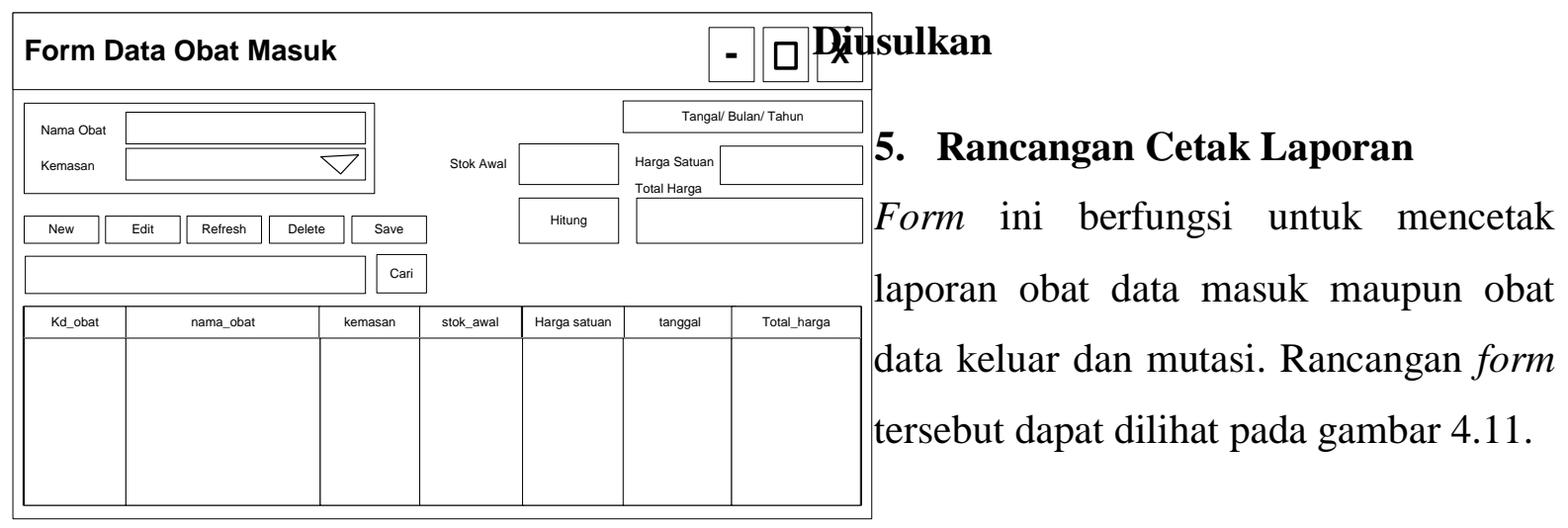

\section{Gambar 4.9 Form Obat Masuk yang}

\section{Diusulkan}


Jurnal Mahasiswa IImu Komputer (JMIK)

Vol. 01, No. 01, Maret 2021

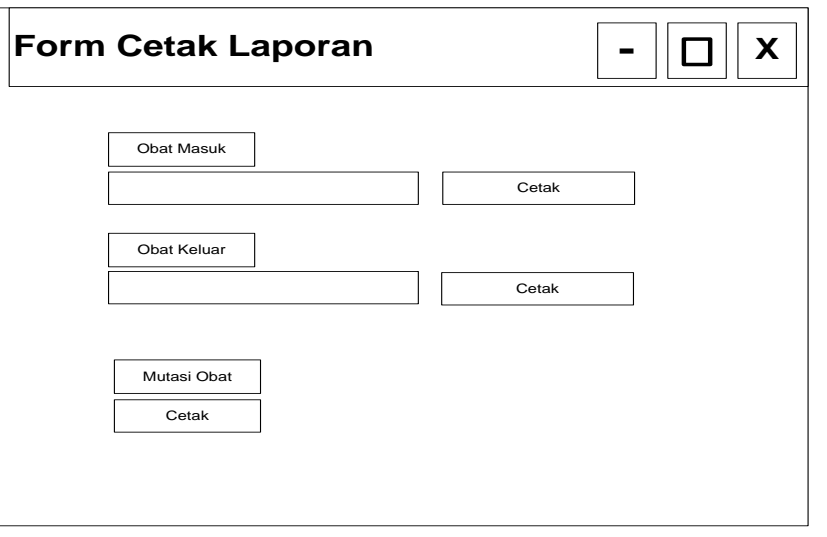

Gambar 4.11 Form Cetak Laporan yang Diusulkan

\section{Rancangan Laporan Data Obat Masuk}

Tampilan ini berfungsi untuk mengetahui laporan data obat masuk . Rancangan tersebut dapat dilihat pada gambar 4.12.

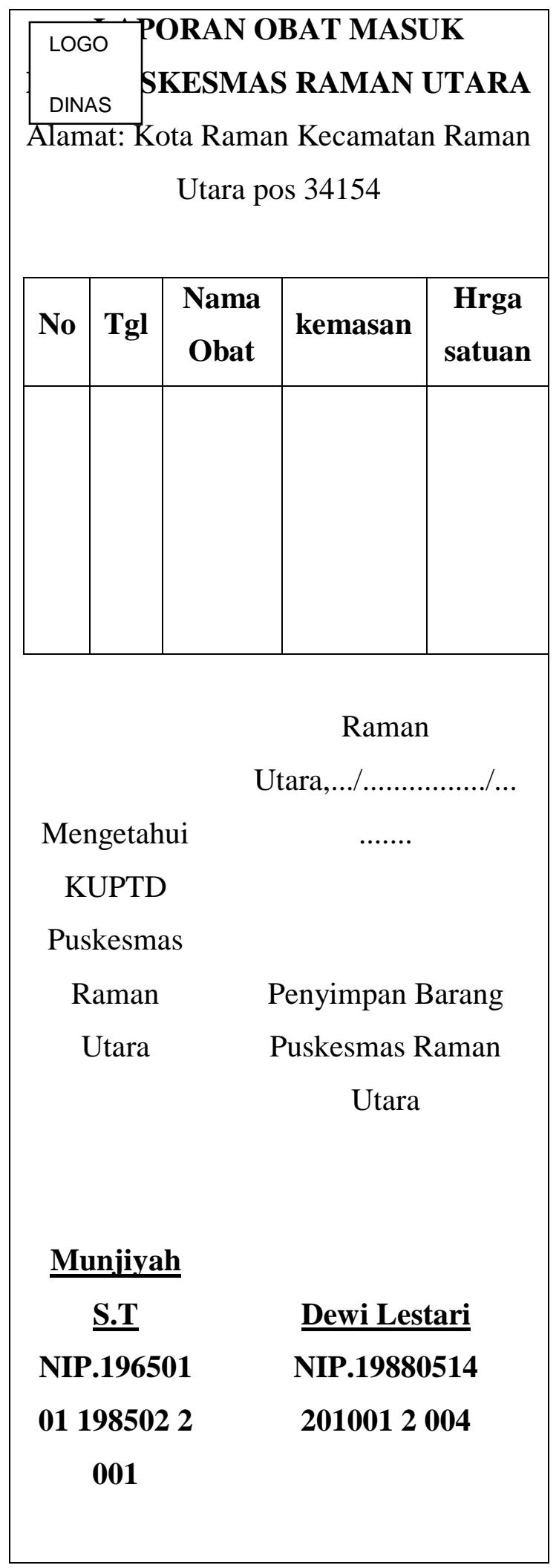


Jurnal Mahasiswa IImu Komputer (JMIK)

Vol. 01, No. 01, Maret 2021

Gambar 4.12 Laporan Obat Masuk yang

Diusulkan

7. Rancangan Laporan Data Obat Keluar

Tampilan ini berfungsi untuk mengetahui laporan data obat keluar . Rancangan tersebut dapat dilihat pada gambar 4.13.

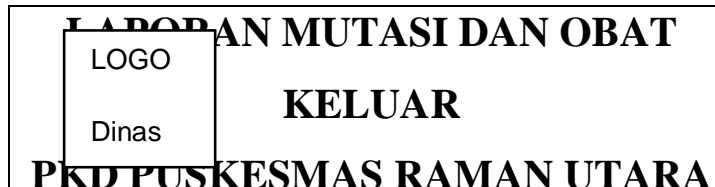

Alamat: Kota Raman Kecamatan Raman

Utara pos 34154

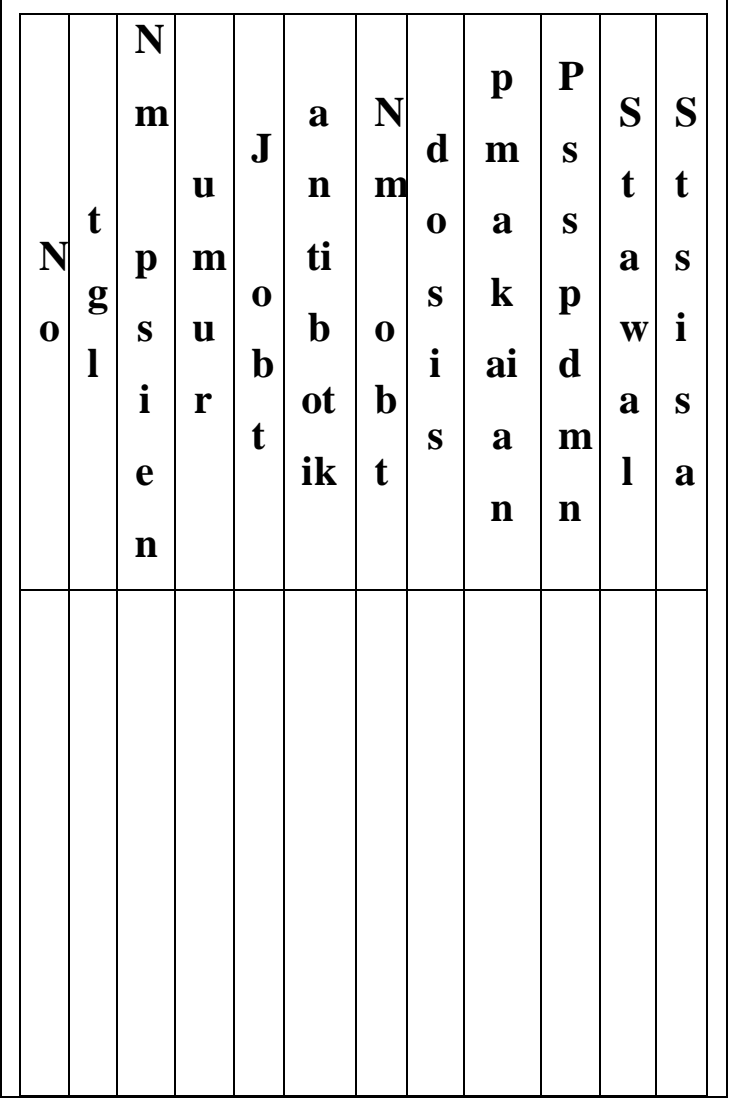

\section{Raman}

Utara, .../....................

Mengetahui

$$
\text { KUPTD }
$$

Puskesmas

Raman Penyimpan Barang

Utara Puskesmas Raman

Utara

LOGO

Munjiyah

Puskes

$\underline{\text { S.T }}$

Dewi Lestari

NIP.196501

NIP.19880514

011985022

2010012004

001

Gambar 4.13 Laporan Data Obat

Keluar yang Diusulkan

\section{Rancangan Laporan Mutasi Obat}

Tampilan ini berfungsi untuk mengetahui laporan data mutasi obat . Rancangan tersebut dapat dilihat pada gambar 4.14. 
Jurnal Mahasiswa IImu Komputer (JMIK)

Vol. 01, No. 01, Maret 2021

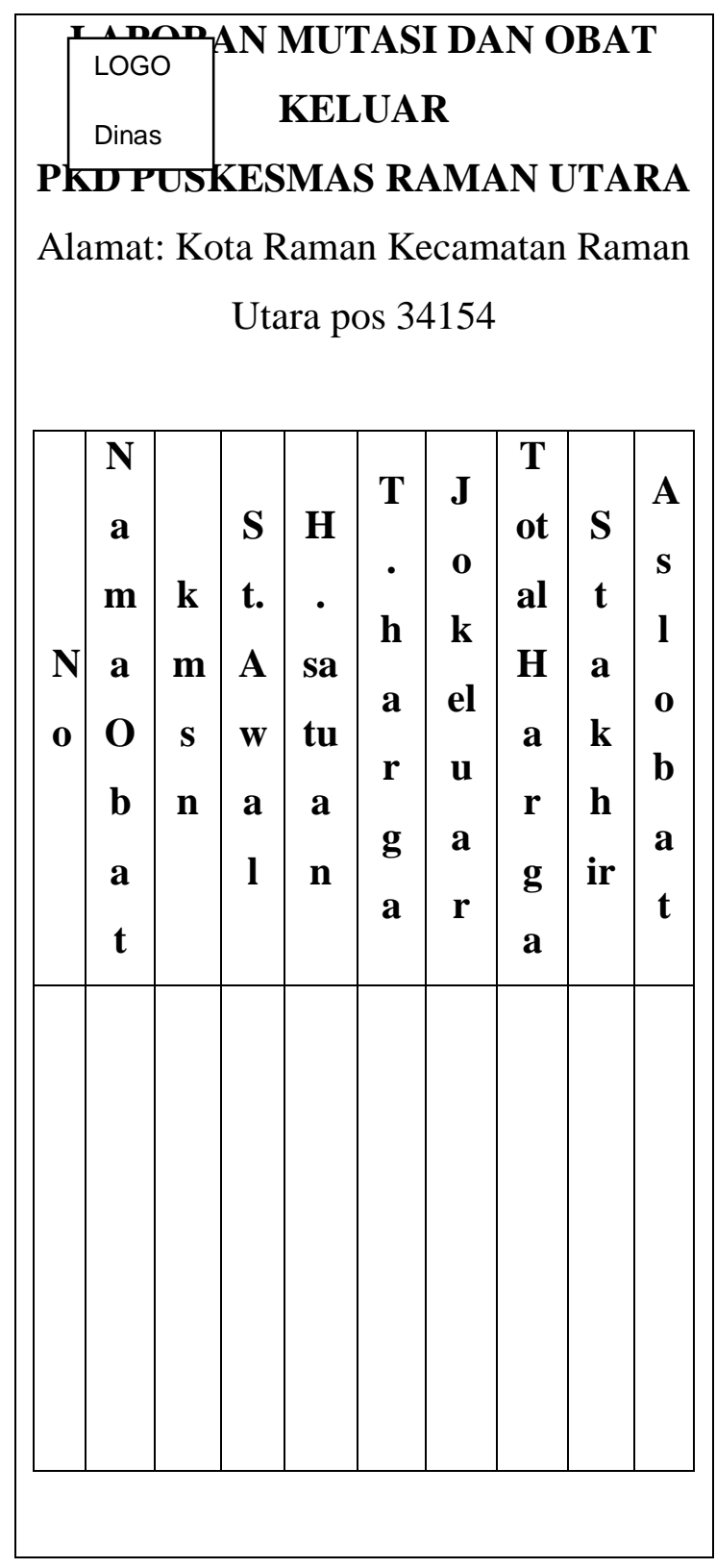

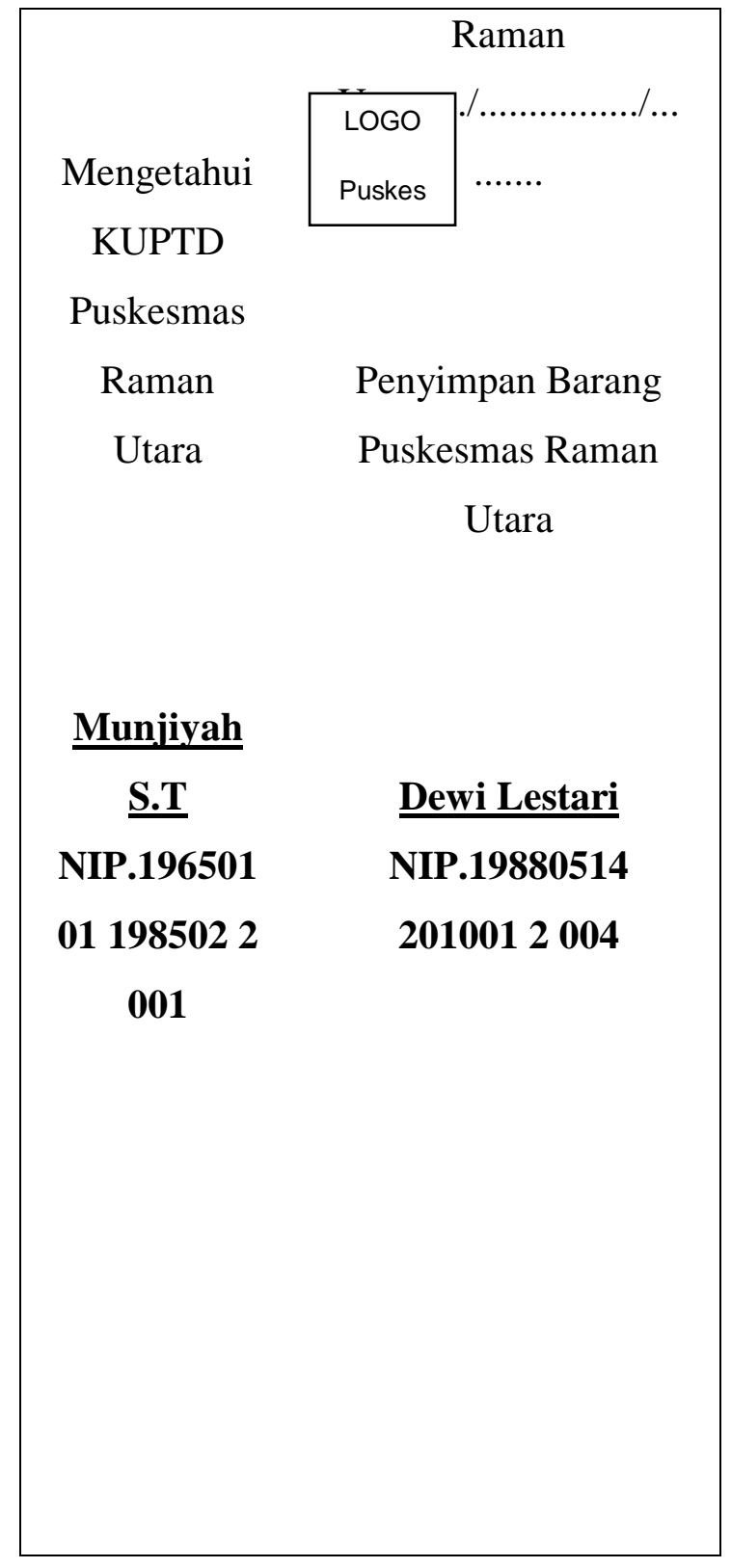

Gambar 4.14 Laporan Data

Mutasi Obat yang Diusulkan

\section{G. Pembahasan Program}

Pembahasan aplikasi bertujuan untuk memberikan interface tentang desain program yang dibuat.

\section{Tampilan Form Login}


Tampilan ini berfungsi sebagai tempat untuk memasukkan username dan password sebagai proses autentifikasi ketika akan melakukan proses penginput-an data obat masuk dan data obat keluar pada PKD (Pusat Kesehatan Dasar) Puskesmas Raman Utara Lampung Timur. Rancangan form login dapat dilihat pada gambar 4.15.

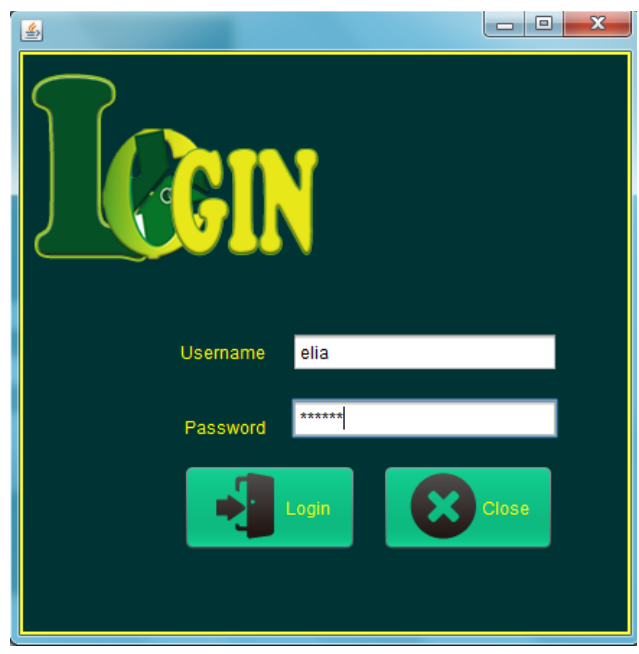

\section{Gambar 4.15 Form Login}

\section{KESIMPULAN}

\section{Kesimpulan}

Pelaksanaan Kuliah Kerja Praktek yang dilaksanakan pada Puskesmas Raman Utara Lampung Timur menghasilkan pemahaman mengenai kendala sistem manajemen pada puskesmas rama utara yaitu terutama dalam memanajemen keluar masuknya obatobatan. Penulis memahami dan menganalisa dalam proses pengolahan mutasi obat yang berlangsung dan dari proses pemahaman dan analisa tersebut penulis dapat merancang Aplikasi Pengolahan Data Mutasi Obat pada PKD Puskesmas Raman Utara Lampung Timur. Sehingga dapat diambil beberapa kesimpulan sebagai berikut.

1. Berdasarkan Perancanagan Aplikasi Pengolahan Data Mutasi Obat pada PKD Puskesmas Raman Utara Lampung Timur dihasilkan login, rancangan input data obat, rancangan input keluaran obat, serta laporan dari obat keluar, obat masuk dan mutasi obat yang dapat dicetak perbulan bahkan harian.

2. Dengan adannya rancangan aplikasi pengolahan data mutasi obat dapat mempermudah sesuai dengan tujuan pembuatan tugas akhir penulis, yaitu Meminimalisir terjadinya kesalahan dalam proses penginputan data, mempercepat proses pencarian data obat.

3. Mempermudah pembuatan laporan data mutasi obat sebagai informasi kepada pegawai untuk dilaporkan ke dinas agar tepat waktu pada Puskesmas Raman Utara Lampung Timur.

\section{Saran}


Vol. 01, No. 01, Maret 2021

Adapun saran-saran yang disampaikan berdasarkan kesimplan diatas adalah sebagai berikut:

1. Aplikasi yang telah diancang oleh penulis ini diharapkan untuk dapat dikembangkan agar menjadi lebiih baik kedepannya menambah fungsionalitas dari aplikasi yang telah dirancang dan penulis membuat aplikasi ini sesuai dengan pengamatan yang dilakukan pada Puskesmas Raman Utara Lampung Timur.

2. Perawatan pada sistem perlu diperhatikan agar sistem ini dapat beroprasi secara maksimal

3. Jika dalam pembuatan aplikasi ini terdapat suatu kekurangan, khususnya dalam hal desain antar muka, penulis berharap untuk pengembangan yang selanjutnya agar lebih baik lagi.

\section{DAFTAR PUSTAKA}

[1] Abdurahman, dkk. 2014. Aplikasi Pinjaman Pembayaran Secara Kredit Pada Bank Yudha Bhakti. Jurnal Computech \& Bisnis vol.8, No.2. ISSN: 2442-4943
[2] Andi. 2002. Java Hanbook Konsep Dasar Pemrograman Java.Yogyakarta: C.V ANDI OFFSERT

[3] Arman. Sistem Informasi Pengolahan Data Penduduk Nagari Tanjung Lolo, Kecamatan Tanjung Gadang, Kabupaten Sijunjung. Jurnal Edik Informatika vol.2. ISSN: 2407-0491

[4] Astuti. 2011. Sistem Informasi Penjualan Obat Pada Apotek Jati Farma Arjosari. Journal Speed vol 3. No 4. ISSN: 1979-9330

[5] Budiharto. 2013. Web Programing Membangun Aplikasi Web Handal Dengan J2EE Dan MVC. Yogyakarta: C.V ANDI OFFSERT

[6] Bukit. 2018. Program Pengolahan Tunjangan Cuti Pegawai Pada PT ASDP Indonesia Ferry. Jurnal Gerbang. Vol.8, No.1.

[7] Hudaya. 2015. Java Dekstop Dengan Metode Pro-OOP. Yogyakarta: C.V ANDI OFFSERT

[8] Jogiyanto. 2005. Analisis Desain, Sistem Informasi: Pendekatan Terstruktur Teori Dan Praktek Aplikasi 
Jurnal Mahasiswa IImu Komputer (JMIK)

Vol. 01, No. 01, Maret 2021

Bisnis.Yogyakarta: $\quad$ C.V ANDI OFFSERT

[9] Kadir. 2009. Dasar Perancangan Dan Implementasi Database Relasional. Yogyakarta: C.V ANDI OFFSERT

[10] Masaleno. 2011. Kamus Istilah Komputer \& Informatika, Panduan Dalam Menyelami Dunia Komputer Dan Informatika. Banguntapan Jogyakata: Flash Books

[11] Mujiati. 2014. Analisis Dan Perancangan Sistem Informasi Stok Obat Pada Apotek Arjowinangun. Jurnal Speed vol.11, No. 2. ISSN: 1979-9330

[12] Purnama, dkk. 2010. Pembangunan Sistem Informasi Pendataan Rakyat Miskin Untuk Program Beras Miskin (Raskin) Pada Desa Mantren Kecamatan Kebonagung Kabupaten Pacitan. Jurnal Speed vol.2, No.4. ISSN: 1979-9330

[13] Saputra, dkk. 2014. Perancangan Sistem Inforasi Penerimaan Siswa Baru Berbasis Web Pada SMK N 6 Muaro Jambi. Jurnal Ilmiah Media vol.8, No. 2. ISSN: 1978-8126
[14] Simarmata, dkk. 2010. Basis Data. Yogyakarta: C.V ANDI OFFSERT

[15] Wahana. 2015. Membangun Sistem Informasi Dengan Java Netbeans Dan MySql. Semarang: C.V ANDI OFFSERT 